\title{
Front Matter: Volume 10761
}

, "Front Matter: Volume 10761," Proc. SPIE 10761, Adaptive X-Ray Optics V, 1076101 (6 November 2018); doi: 10.1117/12.2516844

EDIE Event: SPIE Optical Engineering + Applications, 2018, San Diego, California, SPIE. United States 


\section{PROCEEDINGS OF SPIE}

\section{Adaptive X-Ray Optics V}

Daniele Spiga

Hidekazu Mimura

Editors

21 August 2018

San Diego, California, United States

Sponsored and Published by

SPIE

Volume 10761 
The papers in this volume were part of the technical conference cited on the cover and title page. Papers were selected and subject to review by the editors and conference program committee. Some conference presentations may not be available for publication. Additional papers and presentation recordings may be available online in the SPIE Digital Library at SPIEDigitalLibrary.org.

The papers reflect the work and thoughts of the authors and are published herein as submitted. The publisher is not responsible for the validity of the information or for any outcomes resulting from reliance thereon.

Please use the following format to cite material from these proceedings:

Author(s), "Title of Paper," in Adaptive X-Ray Optics V, edited by Daniele Spiga, Hidekazu Mimura, Proceedings of SPIE Vol. 10761 (SPIE, Bellingham, WA, 2018) Seven-digit Article CID Number.

ISSN: 0277-786X

ISSN: 1996-756X (electronic)

ISBN: 9781510620933

ISBN: 9781510620940 (electronic)

Published by

SPIE

P.O. Box 10, Bellingham, Washington 98227-0010 USA

Telephone +1 3606763290 (Pacific Time) · Fax +1 3606471445

SPIE.org

Copyright (C) 2018, Society of Photo-Optical Instrumentation Engineers.

Copying of material in this book for internal or personal use, or for the internal or personal use of specific clients, beyond the fair use provisions granted by the U.S. Copyright Law is authorized by SPIE subject to payment of copying fees. The Transactional Reporting Service base fee for this volume is $\$ 18.00$ per article (or portion thereof), which should be paid directly to the Copyright Clearance Center (CCC), 222 Rosewood Drive, Danvers, MA 01923. Payment may also be made electronically through CCC Online at copyright.com. Other copying for republication, resale, advertising or promotion, or any form of systematic or multiple reproduction of any material in this book is prohibited except with permission in writing from the publisher. The CCC fee code is 0277$786 \mathrm{X} / 18 / \$ 18.00$

Printed in the United States of America.

Publication of record for individual papers is online in the SPIE Digital Library.

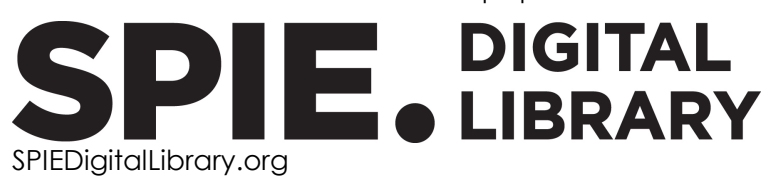

SPIEDigitalLibrary.org

Paper Numbering: Proceedings of SPIE follow an e-First publication model. A unique citation identifier (CID) number is assigned to each article at the time of publication. Utilization of CIDs allows articles to be fully citable as soon as they are published online, and connects the same identifier to all online and print versions of the publication. SPIE uses a seven-digit CID article numbering system structured as follows:

- The first five digits correspond to the SPIE volume number.

- The last two digits indicate publication order within the volume using a Base 36 numbering system employing both numerals and letters. These two-number sets start with 00, 01, 02, 03, 04, 05, 06, 07, 08, 09, OA, OB ... 0Z, followed by 10-1Z, 20-2Z, etc. The CID Number appears on each page of the manuscript. 


\title{
Contents
}

\author{
$\checkmark \quad$ Authors \\ vii Conference Committee \\ ix Introduction
}

SESSION $1 \quad$ FEL APPLICATIONS

$1076102 \quad$ Metrology of micron focusing KB mirrors for SPB/SFX instrument and preliminary commissioning results at European XFEL (Invited Paper) [10761-1]

\section{SESSION 2 METROLOGY AND OPTICAL SIMULATIONS}

1076106 Development of the new long trace profilometer at LCLS for bendable x-ray mirror metrology [10761-6]

1076107 Simulating the optical performances of the LCLS bendable mirrors using a 2D physical optics approach [10761-7]

1076108 Ex-situ metrology and data processing techniques developed at the ALS for optimization of beamline performance of bendable x-ray mirrors (Invited Paper) [10761-5]

\section{SESSION $3 \quad$ NEW DEVICE DEVELOPMENT}

10761 OB Magnetostrictively deforming the surface of a silicon wafer at two locations [10761-1 1]

\section{SESSION 4 AT-WAVELENGTH METROLOGY}

10761 OD Inspecting adaptive optics with at-wavelength wavefront metrology [10761-13]

10761 OF Ptychography simulations for precisely measuring wavefront profiles in soft x-ray focusing system based on ellipsoidal mirror [10761-15]

$10761 \mathrm{OH}$ Real-time feedback for $\mathrm{x}$-ray adaptive optics with an interferometric absolute distance sensor array [10761-17] 
Proc. of SPIE Vol. 10761 1076101-4 Downloaded From: https://www.spiedigitallibrary.org/conference-proceedings-of-spie on 25 Apr 2023
Terms of Use: https://www.spiedigitallibrary.org/terms-of-use 


\section{Authors}

Numbers in the index correspond to the last two digits of the seven-digit citation identifier (CID) article numbering system used in Proceedings of SPIE. The first five digits reflect the volume number. Base 36 numbering is employed for the last two digits and indicates the order of articles within the volume. Numbers start with 00, 01, 02, 03, 04, 05, 06, 07, 08, 09, OA, OB...0Z, followed by 10-1Z, 20-2Z, etc.

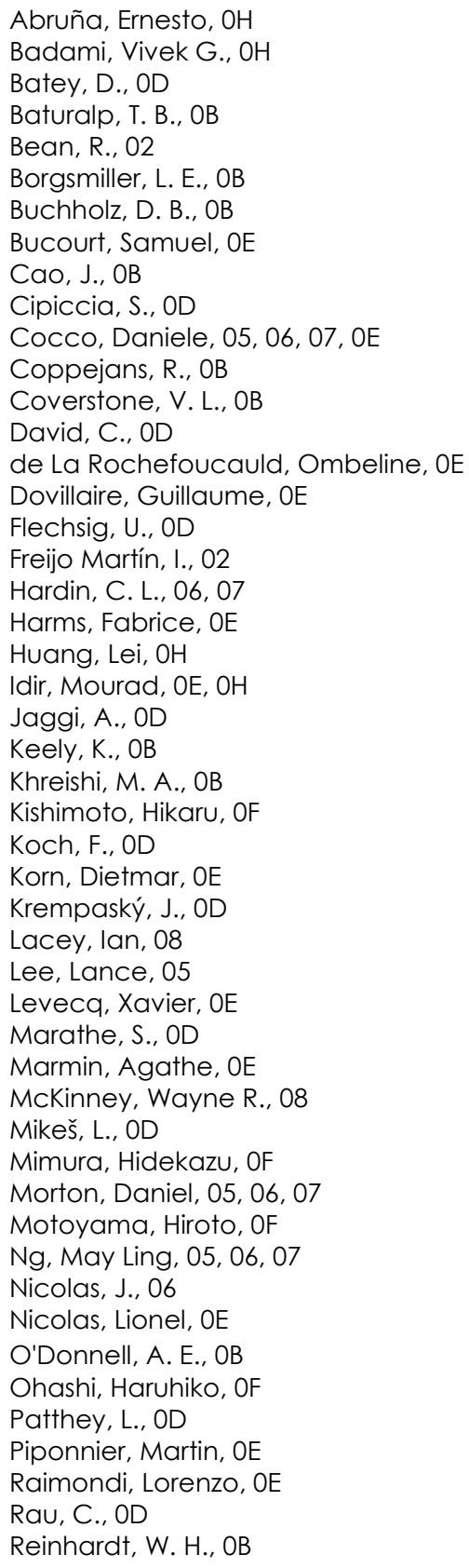

Rodriguez, L. A., OB

Schonfeld, Z. J., OB

Seaberg, M., OD

Seiboth, F., OD

Senba, Yasunori, OF

Shiri, R., OB

Sinn, H., 02

Spiga, D., 06, 07

Svetina, C., OD

Takeo, Yoko, OF

Ulmer, M. P., OB

Vagovič, P., OD

Vannoni, M., 02

Wagner, U. H., OD

Yashchuk, Valeriy V., 08

Zeitoun, Philippe, $\mathrm{OE}$

Zhang, Lin, 05 
Proc. of SPIE Vol. 10761 1076101-6

Downloaded From: https://www.spiedigitallibrary.org/conference-proceedings-of-spie on 25 Apr 2023 Terms of Use: https://www.spiedigitallibrary.org/terms-of-use 


\title{
Conference Committee
}

\author{
Program Chairs
}

Ali M. Khounsary, Illinois Institute of Technology (United States)

Ralph B. James, Savannah River National Laboratory (United States)

\section{Conference Chairs}

Daniele Spiga, SLAC National Accelerator Laboratory (United States) and INAF - Osservatorio Astronomico di Brera (Italy)

Hidekazu Mimura, The University of Tokyo (Japan)

Conference Co-chairs

Mourad Idir, Brookhaven National Laboratory (United States)

Kawal Sawhney, Diamond Light Source Ltd. (United Kingdom)

Maurizio Vannoni, European XFEL GmbH (Germany)

\section{Conference Program Committee}

Raymond Barrett, ESRF - The European Synchrotron (France)

Daniele Cocco, SLAC National Accelerator Laboratory (United States)

Vincenzo Cotroneo, Harvard-Smithsonian Center for Astrophysics (United States)

Ombeline de La Rochefoucauld, Imagine Optic SA (France)

Guillaume Dovillaire, Imagine Optic SA (France)

René Hudec, Astronomical Institute of the CAS, v.v.i. (Czech Republic)

Ali M. Khounsary, Illinois Institute of Technology (United States) Michele Manfredda, Elettra-Sincrotrone Trieste S.C.p.A. (Italy)

Stephen L. O'Dell, NASA Marshall Space Flight Center (United States)

Michael J. Pivovaroff, Lawrence Livermore National Laboratory (United States)

Roberto Ragazzoni, INAF - Osservatorio Astronomico di Padova (Italy)

Daniel A. Schwartz, Harvard-Smithsonian Center for Astrophysics (United States)

Riccardo Signorato, Strumenti Scientifici CINEL s.r.l. (Italy)

John P. Sutter, Diamond Light Source Ltd. (United Kingdom)

Cristian Svetina, Paul Scherrer Institut (Switzerland)

Hisataka Takenaka, TOYAMA Company, Ltd. (Japan)

Melville P. Ulmer, Northwestern University (United States) 
Valentina Viotto, INAF - Osservatorio Astronomico di Padova (Italy) Kazuto Yamauchi, Osaka University (Japan)

Philippe Zeitoun, ENSTA Paristech (France)

\section{Session Chairs}

1 FEL Applications

Hiroki Nakamori, JTEC Corporation (Japan)

2 Metrology and Optical Simulations

Vincenzo Cotroneo, Harvard-Smithsonian Center for Astrophysics (United States)

3 New Device Development

Ombeline de La Rochefoucauld, Imagine Optic SA (France)

4 At-Wavelength Metrology

Melville P. Ulmer, Northwestern University (United States)

Hidekazu Mimura, The University of Tokyo (Japan) 


\section{Introduction}

Adaptive $x$-ray optics is a quite recent branch of optical engineering. Its close relative, i.e., adaptive mirrors for astronomical telescopes, aims at overcoming the disturbance of the atmosphere in astronomical observations by real-time wavefront sensing and correction via rapidly-deformable mirrors. X-ray mirrors, in contrast, operate in high vacuum and so are completely unaffected by air turbulences. Nevertheless, adaptive (or active, or adjustable) x-ray optics has inherited the concept of shape-changing mirrors, in order to correct profile distortions that could not be removed by the manufacturing, integration, or the bearing system. Adaptive x-ray optics furthermore offers the opportunity to actively compensate mirror distortions caused by the thermal load.

This volume encompasses contributions on latest developments of adaptive $x$-ray optics in two fundamental sectors: space observatories and ground-based light sources (synchrotrons and FEL - free electron lasers). The two domains face the same problem of optimizing the focusing accuracy, but with completely different boundary conditions. The former needs to detect faint signals and therefore has to remove surface defects in thin mirrors, typically densely packed in a large aperture optical module. The latter targets at mirror shape control in beamlines near the diffraction limit, under intense, highly-anisotropic radiation exposure. Consequently, different mirror geometries are usually adopted in the two cases.

Despite the differences, indeed, a common physical frame can be drawn around the two realms. Even to different approximation levels, the same elasticity theory rules the mirror bending. The same wavefront propagation controls the bending of $x$-rays throughout the optical system. Thermal gradients - on orbit or in a beamline - distort the wavefront and hinder the focusing performances, and sensitive metrology/wavefront sensing techniques have to be developed to characterize and feedback the mirror correction.

This proceeding volume aims at finding a sharing point between the research being carried out in both branches of adaptive x-ray optics. The papers enclosed in the volume cover the following topics:

- FEL applications, with particular regard to surface metrology of mirrors under coherent, high-intensity radiation

- Metrology and optical simulations, modelling of wavefront propagation, and mirror bending

- New device development in lightweight adaptive x-ray optics

- At-wavelength metrology, wavefront sensing, and feedback techniques.

Daniele Spiga

Hidekazu Mimura 
Proc. of SPIE Vol. 10761 1076101-10

Downloaded From: https://www.spiedigitallibrary.org/conference-proceedings-of-spie on 25 Apr 2023 Terms of Use: https://www.spiedigitallibrary.org/terms-of-use 